\title{
Traits of positive and negative discrimination of the Copts in medieval Egypt as described by the "History of the Patriarchs of Alexandria"
}

\author{
Anastasia M. Ivanova \\ Associate Professor, National Research University Higher School of \\ Economics, St. Petersburg, Russia \\ amivanova@hse.ru
}

\begin{abstract}
In the course of the Middle Ages, the Copts experienced a variety of drastic changes in the attitude of Muslim rulers towards them, from confidence to disgrace. The latter included not only the increasingly rigorous tax policies, but also social and domestic constraints.

The question of the balance between positive and negative discrimination as an instrument of regulating intrastate social cooperation can be crucial for understanding the specific of these relationships during the described period. So, the main goal of this work is to is to trace historical precedents which can be considered either negative or positive discrimination, and their suppositional influence on the Copts' turning into a minority. An essential source for this is the History of the Patriarchs of the Coptic church of Alexandria, the most famous chronicle of the Coptic Church and also the root of Coptic historiography itself, which also gives the view of how the Coptic Church itself assessed its role in Egyptian society and in public policy.
\end{abstract}

\section{Keywords}

Islam - Middle Ages - Copts - religion - discrimination

\section{Introduction}

Since the Arab conquest of Egypt in 641 active development of the religionstate relations began. The evolution of these relations was simultaneous to the changing confessional situation in the country, being as well a process of transformation of the Copts into an ethno-confessional minority. 
After the conquest of Egypt by the Muslim Arabs a new period started in the history of the Copts. Arab rulers did not prohibit the Egyptians to profess Christian faith, which, for the Egyptian Christians, meant the end of persecution of their church. The Coptic "elite" ranked fairly high positions in the administrative apparatus of the Muslim Egypt and had a significant economic impact in the country. But the Copts did not have all the civil rights enjoyed by Muslims and also were required to pay the jizya and kharaj.

On the one hand, the Coptic Church was granted broad internal autonomy. But on the other hand, the integration of the representatives of the Coptic community in the social and political structure of Egypt occurred on the condition of administrative posts being kept by representatives of the Muslim community.

In the course of the Middle Ages, the Copts experienced a variety of drastic changes in the attitude of Muslim rulers towards them, from confidence to disgrace. The latter included not only the increasingly rigorous tax policies, but also social and domestic constraints, which can be surely defined as religious discrimination. Though the Copts managed to regain the trust of the authorities by their profound skills in administrative and courtly functions and, of course, compromise in terms of religion, which allowed them to enjoy high ranks and other benefits of their proximity to the Egyptian court. This, in its turn, made them an outstanding social group and can be considered "positive discrimination" in contrast with the definitely negative discrimination based on confessional conditions.

The problem of complex relationships between the Muslim authorities and the Coptic community has not yet been viewed in the context of the discourse opposition of "positive and negative discrimination", where "negative discrimination" is to be defined as treatment of an individual or group, based on their actual or perceived membership in a certain group or social category, "in a way that is worse than the way people are usually treated", 1 including deprivation of civil rights, restrictions in the performance of acts of worship and application of force while implementing the above. "Positive discrimination" can therefore be defined as a complex of measures that give advantage to the discriminated minorities, subsequently or simultaneously to measures of negative discrimination.

So, the main goal of this work is to trace historical precedents which can be considered either negative or positive discrimination, and their suppositional influence on the Copts' turning into a minority.

1 “discrimination, definition", Cambridge Dictionaries Online, Cambridge University. <https:// dictionary.cambridge.org/dictionary/english/discrimination> (Retrieved o7/og/2018). 
This work is an introductory study based on a variety of scientific works, with three Arabic chronicles used as primary sources. The first is A Short History of the Copts and their Church by al-Maqrīzi (1364-1442), a Mamluk era historian who had a keen interest in the Isma'ili Fatimīd dynasty and its role in Egyptian history. ${ }^{2}$ The second is The history of Coptic community by Ya'qub Nakhlah Rufaylah, one of the most famous Coptic chronicles in Arabic among the many published in Cairo in the XIXth century. The last, but not the least, is the History of the Patriarchs of the Coptic church of Alexandria (henceforth H PA), the most famous chronicle of the Coptic Church and also the root of Coptic historiography itself. Coptic sources may be subjective, ${ }^{3}$ but thanks to this subjectivity they give the view of how the Coptic Church itself assessed its role in Egyptian society and in public policy. They also allow us to touch such an important area as national memory stored in the Coptic tradition. And this memory, in turn, makes it possible to better understand the nature of church-state relations and the station of the Coptic community. The special value of the Coptic sources is that they are based on church archives, as well as documents and manuscripts in Coptic monasteries of Egypt.

The target of research for this paper is the complex relationship between Muslim authorities of medieval Egypt and the Coptic community of the latter, the subject of research being the dynamics of intrastate relationships involving the Copts. The chronological frameworks of the inquiry are the Middle ages, from the conquest of Egypt to the middle of Ayyubìd reign, approximately VIIth to XIIIth centuries.

This study does not claim to comprehensive coverage of the issue, but the question of the balance between positive and negative discrimination as an instrument of regulating intrastate social cooperation can be crucial for understanding the specific of these relationships during the described period.

\section{Historical Background and Precedents of Discrimination of the Copts in Medieval Egypt}

In 641 Egypt was conquered by the Arab military commander of Caliph 'Omar - 'Amr ibn al-'As. The Arabs came to calling the local population "qubt", derived from the Greek word Aigýptios modified to Arabic. Gradually, the term

2 P.E. Walker, Exploring an Islamic Empire: Fatimid History and its Sources, London, 2002, p. 164.

3 J. Den Heijer, Mawhub ibn Mansur ibn Mufarrig et l'Historiographie Copto-Arabe (Étude sur la Composition de l'Histoire des Patriarches d'Alexandrie), (csco 513, Subs. 83), Lovania, 1989. 
"Copts" grew to be assigned to the Egyptian Christians, contrasting them with the Muslims and Christians of non-Egyptian origin.

The extremely quick and relatively easy conquest of Egypt by the Arabs (639-642) was due to several factors. In addition to the weakening of the Byzantine Empire in the virth century, the support from the Coptic population was also an important reason for the successful completion of the campaign. Although later sources gravitate towards an opinion that most of the Egyptian population viewed Arabs as transitory occupiers and it was not until the late seventh century that the latter started to be perceived as a permanent presence. ${ }^{4}$ Some sources underline the fact that Copts (whose church has recently gone through its first radical bifurcation $)^{5}$ and Byzantines had some religionbased tension between themselves, which led to the emergence of 'nationalistic' tendencies among the Copts. And this 'nationalism' theory does not contribute, along with some of the Vth-vith century sources, to the fact that Arabs were welcomed by the Coptic community. ${ }^{6}$

Rapprochement between Arabs and Egyptian Copts was encouraged by liberal religious and economic policies ${ }^{7}$ of the Muslim authorities. As 'Amr forbade looting for the army, several cases of destruction of churches that have taken place at the beginning of the Arab presence in Egypt have not affected the religious life of the Egyptian Christians. ${ }^{8}$ Monasteries also enjoyed the patronage of Arabs. At first the monks did not pay the capitation tax, and monasteries and monastic land were also not taxed, as well as the land of Muslim religious institutions (waqf). Thus, the Church (as an institution) enjoyed a special position, while all the non-Muslims had to pay the poll tax (jizya), apart from the land tax (kharaj) that was mandatory for all. ${ }^{9}$

This policy of tolerance changed by the middle of the viIIth century, under Caliph Marwān II (744-750), ${ }^{10}$ whose reign was marked by particular cruelty to

Lois M. Farag, The Coptic Christian Heritage: History, Faith and Culture, Routledge, 2013, p.40.

5 P. Booth, "Towards the Coptic Church:The Making of the Severan Episcopate," Millennium, 14 (1) (2017), pp. 151-19o.

6 E. Wipszycka, «Le Nationalisme a-t-il Existe dans l'Egypte Byzantine,» Journal of Juristic Papyrology, XXII (1992), pp. 83-128.

7 A.J. Butler, The Arab Conquest of Egypt and the Last Thirty Years of the Roman Dominion, Oxford, 1902, p. 433.

8 P. Hitti, The Origins of the Islamic State. Part I, New York, 2011, p. 207.

9 О.Г. Большаков, История халифата. Т.2. Эпоха великих завоеваний (633-656) [O.G. Bolshakov, History of the Caliphate. V.2. The Age of Great Conquests (633-656)], Moscow, 2002, p. 53 .

10 Dates here and henceforth given as in S. Lane-Poole, The Mohammedan Dynasties: Chronological and Genealogical Tables with Historical Introductions, London, 2018. 
the Egyptian monks. The reasons for persecution of Christians were uprisings, caused, in turn, by the tax burden. The first Coptic uprisings, in 725 in the Delta area and in 739 in Upper Egypt, were brutally suppressed. A total of six major uprisings between 725 and 773 has been reported. The failure of these revolts led only to increase in the authority of the conquerors, and thus, that of the number of Coptic converts to Islam. The burden of taxes, in particular, jizya and kharaj, the collection of which often implemented iniquity and violence, as well as frequent additional fees introduced by some rulers, forced Copts to accept Islam.

According to the Coptic sources, "... some of the Copts, to be rid of requisitions and gain privileges enjoyed by the Muslims, embraced Islam". ${ }^{11}$ However, this led to a significant decrease of state treasury income, and so some rulers imposed poll tax on the Egyptian monks who initially had tax immunity.

Conversion to Islam opened the possibility of integrating into the privileged Muslim class and avoiding heavy additional levies and restrictions on tax-paying population. However, "when the Umayyad rulers realized that the Copts convert to Islam to avoid paying jizya, they decreed that those who accepted Islam would not be freed of jizya and must continue paying it". ${ }^{12}$ So, it was only the first two years through all the Umayyad period when the Christians who converted to Islam were free from the poll tax.

Meanwhile, the islamization of the Christian population was quite intensive. This was also enhanced by mixed marriages between Muslims and Christian women, as children born to them became Muslims. Consequently, the arabization naturally led to islamization. At the same time the number of the Arab immigrants from Arabia settling in Egypt kept increasing.

While speaking about the intensity of this migration it should be said that the very frequent statement of Arabic sources about the mass conversions of Copts to Islam in the first decade after the Arab conquest is not supported by historical facts. By $725,98 \%$ of Egyptians continued practicing Christianity. ${ }^{13}$ But in 740 the first mass conversion of Copts to Islam occurred, caused by the brutal suppression of the first two uprisings and leading to mass persecution of the Egyptian Christians. ${ }^{14}$ It was probably the Ixth century when the Copts

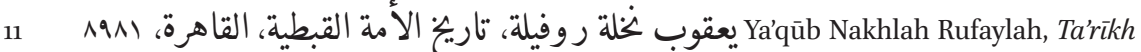
al-Umma al-Qibtīya [The history of Coptic community], "Cairo, 1898, p. 71. Rufaylah, Tárīkh al-Umma al-Qibtīya, p. 71. 
had ceased to be a numerical majority (in fact, in this century, we find the last mention of the Coptic uprisings). ${ }^{15}$

Processes of Islamization and Arabization of the Egyptian population were greatly aided by the gradual acceptance of Arabic as the working language of local administrative bodies. In 706, 'Abd Allah ibn 'Abd al-Mālik (705-709) signed a decree on administrative documents to be recorded in Arabic. ${ }^{16}$ According to the French historian André Raymond, the first papyrus in Arabic is dated $709 .{ }^{17}$

Through the adoption of Arabic as an official working language of the local administration the governor 'Abd al-Mālik sought to plant the Arabic administrative system in Egypt. This was caused by the fact that the Copts, due to higher cultural level, managed to take prestige social niches in Muslim Egypt, including those in administrative apparatus. Occupying the positions of scribes, officials, record managers, doctors, doing jewellery business and trade, the Copts competed with the Muslims in these areas, monopolizing a number of fiscal, notary and direct administrative functions. ${ }^{18}$ When 'Abd Allah ibn 'Abd al-Mālik stripped the Copts of their assigned positions of scribes in the diwans, ${ }^{19}$ translating official correspondence and paperwork into Arabic, Copts had no choice but to learn it.

The linguistic shift could be facilitated by a number of factors. The first was the lack of a pressing need to use Coptic in order to live in Egypt as a Muslim. Marriages between Muslims and converted Copts were a second reason. Children in a union between a convert and a lifelong Muslim were predisposed to learn Arabic. Finally, moving to an urban center or just living in a close proximity of a Muslim community would make the process of language acquisition easier. Adults became fluent in Arabic while conducting business and formed new social networks, and children adopted the language through peer interactions and later through religious schools. ${ }^{20}$

According to Rufaylah, "the administrative and financial affairs were conducted by the Copts. And when they found out about all these changes, a great concern overcame them because they might lose their important position in

15 Vatikiotis, The Modern History of Egypt, p. 7.

16 A. Papaconstantinou, "They Shall Speak the Arabic Language and Take Pride in it": Reconsidering the Fate of Coptic after the Arab Conquest," Le Muséon, 120 (3-4) (2007), p. 278.

17 Raymond, Cairo, p.12.

18 C. Roberts, Manuscript, Society, and Belief in Early Christian Egypt, Oxford, 1979, p. 51.

19 Raymond, Cairo, p. 25.

20 S.A. Mikhail Maged, From Byzantine to Islamic Egypt:Religion, Identity and Politics After the Arab Conquest, I.B. Tauris, 2014, p. 94. 
the government. Then they decided to learn the Arabic language with diligence, and achieved the desired goal and perfectly mastered the art of writing and counting in it." ${ }^{21}$

Religious and political conflicts that shook the Arab caliphate and led to the replacement of the Umayyad dynasty by the 'Abbasids echoed in Egypt. 'Abbasids ruled Egypt with the same heavy-handed regime as the Umayyads. 'Abbasid governors of Egypt introduced informal fees despite the official taxes being very high. The "History of the patriarchs of Alexandria" notes on this: “... for the Copts had been robbed of every thing time after time by the adversaries who hated them". ${ }^{22}$ In response to the tax oppression, the Copts repeatedly raised revolts and uprisings, which were violently suppressed. However, these persecutions were isolated and determined not by a deliberate policy of the dynasty, but by the will of specific rulers. ${ }^{23}$

Against the background of socio-political unrest caused by frequent changes of ruling dynasties in medieval Egypt, the persecution against Christians was rather a display of feudal oppression, than religious persecution. According to some researchers, these are isolated cases of persecution, which developed into a stable trend along with the decline of the caliphate. ${ }^{24}$

HPA reports on the times of political unrest after the death of Harūn alRashīd: "In those days Harūn al-Rashīd had died at Bagdad; and his son Muhammad, called Al-'Aminn, sat in his father's place. The cause of offence was that Harūn ar-Rashīd before his death had assembled the chief personages of the empire, and said to them: «After me, the caliphate belongs to my son, the lord Al-Ma'mūn.» But when Muhammad al-'Amīn heard of this, he was filled with anger, and gathered a host together, and made war upon his brother. But Al-Ma'mun killed Al-'Amīn, and sat upon the throne of the empire. When the strife broke out between the two brothers, a certain rebel arose, and assembled an innumerable army, and kept the road between Egypt and the East. And he robbed those that were journeying to Misr or Upper Egypt or Abyssinia or Nubia of all their goods; so that travelling was interrupted on the roads and all the tracks through fear of him. This attack upon Egypt lasted long on account of

\footnotetext{
21 Rufaylah, Ta'rīkh al-Umma al-Qibtīya, p. 68.

22 B. Evetts, History of the Patriarchs of the Coptic Church of Alexandria IV. Patrologia Orientalis, vol. $x$, Paris, 1915, p. 431.

23 O. Meinardus, Christian Egypt Faith and Life, Cairo, 1970, p. 267.

24 К.А. Панченко, Османская империя и судьбы православия на арабском Востоке (XVIнач. ХІХв.) [K.A. Panchenko, The Ottoman Empire and the Fates of Orthodoxy in the Arabic Middle East (XVI-XIX)], Moscow, 1998, p. 9.
} 
the disturbed state of the government of Bagdad. And the insurgents rose against the government in Egypt, and gathered the taxes for themselves."25

The outstanding Russian scholar V. Bartold also notes that "in times of political unrest the rights of Christians and all other gentiles are violated more than any other..... ${ }^{26}$ The social status of Christians was unequal to the position of Muslims in the Egyptian society. Therefore, due to their active participation in trade and usury, they often become victims of social and economic oppression. Although, of course, during the times of political turmoil Muslims got the very same level of economical oppression as non-Muslims. The main reason for conflict were violations of the system of rules regulating the coexistence of Muslim and non-Muslim communities, which has been developed with Muslim law and living practice and based on a number of mutual obligations. In exchange for the commitment of the Muslim community to "provide protection" (dhimma) to some heterodox groups, the latter were required to maintain loyalty to the Muslim authorities, to pay the poll tax (jizya) and comply with a number of social and domestic constraints. In the course of time, the list of restrictions imposed on non-Muslims was slightly enlarged. According to V. Barthold, "[in the second] half of the Ixth century the standing of Christians in Muslim countries is getting worse than before ... However, the standing of Christians did not always meet the requirements of the Qur'an on the payment of taxes 'in humiliation' and the requirements of the so-called contract of 'Omar on distinctions in clothing. Christian officials dressed as noble Muslims and behaved as arrogant with the crowd; this caused protests against the 'dominance' of Christians, sometimes leading to violence". ${ }^{27}$

So, despite the relative tolerance that prevailed in the Egyptian society under Tulunīds (868-905), Ihshidīds (935-96o) and Fatimīds (969-1171), there was a period of mass persecution of non-Muslims under Caliph al-Hākim (9961021). According to al-Maqrizi, at that time "there was such deprivation which no Christian ever experienced. This happened because some of them continued to hold positions of the viziers, had a great influence, enjoyed honors, occupied a high position and posts in the state and had an abundance of their riches ... Al-Hākim was so angry that he could not control himself with rage". 28 He beheaded several high-up Copts, and then restored the old law requiring

\footnotetext{
25 Evetts, History of the Patriarchs IV, p. 446.

26 В.В.Бартольд, Культура мусульманства [V.V. Bartold, Culture of Islam], Moscow, 1998, p. 25 .

27 Бартольд, Культура мусульманства, pр. 24-25.

28 Ahmad lbn Al-Makrizi, A Short History of the Copts and their Church (1873), transl. by S.C. Malan, London, 2009, p. 62.
} 
Christians to wear certain clothes. It is quite significant that in the first decade of his reign religious minorities enjoyed traditional religious freedom.

The peak of repression occurred between 1008 and 1015. At first only the Sunnis were persecuted, and then the repressive policy spread to Christians and Jews. Christians had to wear heavy wooden crosses on their necks. Church fêtes and bell-ringing were prohibited; images of crosses were removed from the outer walls of the churches, any traces covered. Numerous churches were destroyed.

Besides that, Christians lost their high positions in the Egyptian administrative apparatus. ${ }^{29}$ Fear caused by inexplicably cruel oppressions on non-Muslims has prompted many noble Christians, who wanted to maintain their position and status, to convert to Islam. Their example was followed by many commoners. After 1015 the prosecutions were discontinued, and the successors of al-Hākim totally restored the tolerant attitude towards Christians and Jews. This suggests that the extremes of al-Hākim's religious policy were rather an exception to the general rule of relative tolerance that flourished in the Medieval Egyptian society. His successor, al-Zāhir (1021-1036) allowed those converted to Islam by force to return to their former faith. The reign of al-Hākim was the turning point of Egyptian history: the beginning of the mass adoption of Islam by Christians and their inclusion in the Fatimìd political system. ${ }^{30}$

In general, the Fatimīds showed remarkable tolerance toward Christianity. According to a specialist in socio-political history of the Coptic community Otto Meinardus, such favorable attitude of the Fatimid rulers to the Copts came down to their affiliation to the extreme Shiite movement of Ismailism that Egyptian Muslims never accepted, remaining Sunnis and generally maintaining their religious freedom. ${ }^{31}$ Therefore, the Fatimìds tolerated both the Christians and the Egyptian Sunni Muslims, while not finding absolute spiritual and religious unity with any of these groups. At the same time, they patronized the Copts, which is partly due to isolation of the Fatimìd dynasty from the Muslim population of the country. Fatimìd rulers took part in feasts and ceremonies of the Coptic community, and willingly accepted the Copts to public service. Under Caliph al-'Azīz (975-996), Christians were even allowed into the family circle of the Caliph - al-'Aziz had Christian relatives-in-law.

Under the Fatimìd reign the process of ethnogenesis and synthesis of the two subcultures - Coptic and Arabic, - has generally come to an end. Local

\footnotetext{
29 O. Meinardus, Christian Egypt, Ancient and Modern, Cairo, 1977, p. 10.

30 J. Tagher, Christians in Muslim Egypt: A Historical Study of the Relations between Copts and Muslims from 640 to 1922, Altenberge: Oros Verlage, 1998, p. 158.

$31 \quad$ Meinardus, Christian Egypt, Ancient and Modern, p. 11.
} 
political elites began to emerge from the local population and not from the arriving Arabian tribes. In general, during this period, Egypt has ceased to be a purely Christian country.

The invasion of the country by Turkic commander Shirkūh (1169), uncle of Salāh ad-Dīn, ended the rule of the Fatimìds and started the new era of Ayyubìd dynasty (1169-1252). This period was not marked by persecution or violence of the rulers against Christians. However, the Crusades that occurred during the Ayyubìd reign influenced the increase of interreligious tension in the country. Crusaders challenged the Islamic authorities, but the Copts, like other Eastern Christians, maintained neutrality, playing the role of loyal Christian subjects. The Copts did not consider Western newcomers as liberators, especially since the Crusaders themselves despised Eastern Christians as "schismatics". Prolonged wars fought between the Ayyubîds and the Crusaders did not, in general, bring harm to the standing of the Copts in the state. However, Egyptian Christians fully experiences the effects of the Crusades. The "defenders of the Christian faith and Christians" robbed villages, killing their inhabitants and taking women captive. Their cruelty induced hate towards Christians in the hearts of Muslims, without any distinction between Catholic, Orthodox or Monophysite. ${ }^{32}$

Such tense situation has also created unlimited opportunities for various kinds of provocations and denunciations against the Copts. E.g., they have been repeatedly accused of secret assistance to the Francs, which entailed both expropriation of church property, and difficulties in the appointment of the patriarch, ${ }^{33}$ as for the approval of a new patriarch permission of the Muslim authorities was needed.

Thus, the position of the Copts under the Ayyubīds was largely similar to that which they occupied under Fatimid caliphs. Having gained the trust of the authorities under the Fatimìds through dedicated service to Egyptian rulers, the Copts as well kept enjoying the protection of the Ayyubìds. During their reign the country prospered and the community generally retained comfort.

The Mamlūk (1250-1517) coming to power significantly influenced the fate of Egyptian Christians. It is remarkable that the Mamluk reign interrupted the bonds between Egypt and southern European Mediterranean, striking a line between the Greco-Roman and Islamic eras of Egyptian history. ${ }^{34}$

\footnotetext{
32 A.S. Atiya, Tarikh al-massihiya al-sharqiya [History of Eastern Christianity], Cairo, 2005, p. 248.

34 Е.И. Зеленев, Египет: средние века и новое время [E.I. Zelenev, Egypt: Middle Ages and Modern Era], Saint-Petersburg, 1999, p. 100.
} 
It is worth noting that the post of vizier, who traditionally had a great influence at the court of the Mamluk sultans, was usually occupied by Egyptians, often Copts who formally accepted Islam, in fact secretly keeping their Christian faith. Sometimes the vizier took a Muslim name, while remaining a Christian. The diwān administers that formed the structural basis of the Mamluk bureaucracy were subordinate to the vizier. Nevertheless, between 1279 and 1447 Mamluk rulers destituted Copts from high administrative posts eight times.

Crucial reduction in the number of Coptic population by the XIVth century was largely due to Christian conversions to Islam. The last mass acceptance of Islam by Copts was as a result of the incident that took place in 1321, making a crushing blow to the Copts. Shams al-Riāsa Abul Barakat ibn Kabar, a former secretary of the Sultan Rukn al-Dīn Baibars al-Jashnakīr (1309-1309), was captured by the Egyptian authorities for his arrogant and insolent treatment of a crowd of Muslims. ${ }^{35}$ He was saved from death by a Mamluk emir, who took him into his service. However, the repression subsequent to these events that caused the indignation of the Muslim population forced many Christian scribes in the service of the sultan and emirs to accept Islam. Moreover, "the scribes who converted to Islam were able to retain their posts, and those who did not do so were beheaded". ${ }^{36}$ Notary certificates on the conversion to Islam were being drawn up and after that the Copts once again announced accepting Islam in the presence of $q \bar{a} d i .{ }^{37}$ Perhaps this was done to avoid the above-mentioned cases of formal adoption of Islam. Though, presumptively, this procedure was of moral character and was aimed to calm the Muslim population and mitigate its resentment.

However, in contrast to the damage done to Egyptian Christianity as a result of these events, the Coptic officials were not badly affected. Maqrizi gave his assessment of what happened: "From the despised people they became respected and honored... They converted to Islam for the sake of benefit and peace, however, once free, they did not become Muslims."38

These events took place during a period of political instability, exacerbated by a plague epidemic, which was accompanied by a loss of cattle and hunger. In 1347-1349 the plague claimed the lives of one third of the Egyptians. Between 1348 and 1513 there were 18 outbreaks of plague, which led to a reduction in the total population number. In turn, this led to a sharp decrease in cash inflow to

35 Meinardus, Christian Egypt, Ancient and Modern, p. 11.

36 Al-Makrizi, A Short History, Tr. by Malan, p. 73 .

37 Al-Makrizi, A Short History, Tr. by Malan, p.74.

38 Al-Makrizi, A Short History, Tr. by Malan, p. 78. 
the public coffers. So a growing number of informal taxes emerged, which led to riots and revolts among the population. ${ }^{39}$

However, the resentment of the Christian population met particularly brutal massacre, which was due to the low social status of Coptic population. By the middle of the XIVth century the repressive measures against the Copts applied by the Mamluk Sultan al-Sālih ibn Qalawūn (1351-1354) reached an extreme rate: churches and monasteries have been destroyed, their land property expropriated, taxes doubled. Those who resisted were executed. ${ }^{40}$ Terrible plague epidemics completed the picture of the disaster, upon which the act of the tragedy of the Egyptian Mamluk Empire, which resulted in a bloody feud between two Mamluk factions in $1495 \cdot{ }^{41}$

Religion-state relations in medieval Egypt naturally reflected the political and socio-economic interests of both sides in a relatively liberal religious climate in the country and serious restrictions of economic independence of the Church by the Egyptian authorities. Coptic Church, in spite of its considerable powers, continued to depend on the will of the rulers in a number of vital issues, e.g. the appointment of the patriarch and restoration of the ecclesiastic buildings.

\section{Episodes of Positive and Negative Discrimination of the Coptic Community as Described and Assessed by the "History of the Patriarchs ..."}

It was decided to use the History of the Patriarchs of the Coptic church of Alexandria in this study for it being the most famous chronicle of the Coptic Church and also the root of Coptic historiography itself. Authors writing many years (sometimes even hundreds of years) after the events described did not aim to give a faithful account of the past, which was distant and obscure. They would rather compose their texts according to their own literary taste. The text reedited in this way became a more impressive literature piece and thus more interesting for the future wide audiences, ${ }^{42}$ so Coptic sources are known for being subjective, but thanks to this subjectivity they give the view of how the Coptic Church itself assessed its role in Egyptian society and in public policy. They also allow us to touch such an important area as national memory stored

39 Raymond, Cairo, p. 155.

40 Raymond, Cairo, p.16o.

41 Зеленев, Eгипет, p. 148, p. 151.

42 E. Wipszycka, "On the Governor's Jurisdiction During the Persecution of Christians," in: Au-delà des Frontières II, ed. M. Zablocka et al., Warsaw, 200o, pp. 1080-1081. 
in the Coptic tradition. And this memory, in turn, makes it possible to better understand the nature of church-state relations and the station of the Coptic community. The special value of the Coptic sources is that they are based on church archives, as well as documents and manuscripts in Coptic monasteries of Egypt.

The chronicle consists of an introductory part containing four prefaces and a chapter named "The priesthood of Christ", an apologue used as an epigraph for the chronicle. This introduction is followed by the chronicle itself, in which the events are distributed according to the order of the patriarchs elevated to the rank. Such organization of the manuscript is very convenient for comparison of different chronicles and further analysis. ${ }^{43}$ The chapters cover the biographies of Coptic patriarchs up to 1927. This paper will focus on the parts covering the events from year 661 up to the year 1216 .

The work on the HPA is attributed to many eminent figures of Coptic history, e.g. Michael, bishop of Tinnis, Mawhūb ibn Mansūr ibn Mufarrig, deacon of Alexandria and Pope Mark III of Alexandria. ${ }^{44}$

The "History of the patriarchs..." gives a detailed account of the conquest of Egypt by 'Amr Ibn al-'As and even mentions the dhimma treaty, though calling it "The Law": "As for the province of Egypt and any city that agrees with its inhabitants to pay the land-tax to you, and to submit to your authority, make a treaty with them, and do them no injury. But plunder and take as prisoners those that will not consent to this and resist you". 45

This information does totally agree with the accounts of these events in Muslim sources, e.g. al-Balādhuri's "Kitāb futūh al-buldān": "Amr made the citizens of the town dhimmis and laid jizya and kharaj upon them. $<\ldots>$ and while they obey this letter, the Muslims will not harm them."46

It is very peculiar that while describing the rivalries between Muslims and Byzantines H PA indicates the latter as "infidels" or "misbelievers", and simultaneously praises the justice and nobility of 'Amr ibn al-'As. ${ }^{47}$

Basing on the further accounts by the HPA, it can be stated that the coexistence of the two fractions was quite peaceful, from the point of view of the

43 P. Pilette, «L'Histoire des Patriarches d'Alexandrie : Une Nouvelle Evaluation de la Configuration du Texte en Recensions», Le Muséon, 126/3-4 (2013), pp. 419-450.

44 For the list of the authors see J. Den Heijer, "History of the Patriarchs of Alexandria" in The Coptic Encyclopedia Vol. IV, New York, 1991, pp. 1238-1241.

45 B. Evetts, History of the Patriarchs of the Coptic Church of Alexandria II. Patrologia Orientalis, vol. I, Paris, 1907, p. 494.

46 Л.И. Надирадзе, Хрестоматия по истории халифата [L.I. Nadiradze, Chrestomathy on the History of the Caliphate], Moscow, 1968, pp. 97-98.

Evetts, History of the Patriarchs II, p. 496 
Copts. For example, under the reign of governor 'Abd al-'Aziz ibn Marwān ibn al-Hakam (685-705) several churches were built and many other improvements were made, including the restoration of the city of Alexandria. In their turn, the Copts, led by patriarch Simon, were doing their best to avoid conflict between Christians and Muslims. ${ }^{48}$

'Abd al-'Aziz hoped that his son, al-'Asbagh, would succeed him as governor of Egypt, and thus gave him a wide authority over the country, including the collection of taxes. But al-Asbagh was a "a hater of the Christians, a shedder of blood, a wicked man",49 and the following account of his deeds makes it possible that in the eyes of the Copts, the period of persecution started even before the infamous rule of Caliph Marwān II. This account also contains the first evidence of the poll-tax being extended upon Coptic monks: "Now this tax of the infidel Al-'Asbagh was the first poll-tax paid by the monks."

The neighboring paragraphs of the chronicle also mention that "he forced many persons to become Muslims, among them being Peter, governor of Upper Egypt, and his brother Theodore, and the son of Theophanes, governor of Maryūt, and a body of priests and laymen not to be numbered on account of their multitude", which contributes to the fact that it was under the Umayyad rule when mass conversions of the Copts to Islam had begun. Soon after these events, in 717 , Caliph 'Umar came to power, and this is what HPA accounts on his reign:

"Omar, son of Abd al-Azīz, though he did much good before men, acted ill before God. He commanded that there should be no taxes upon the property of the church and the bishops, and began to set the churches and bishops free from the impost on land; and he abolished the new taxes, and rebuilt the ruined cities; and the Christians were in security and prosperity, and so were the churches. But after that be began to do evil; for he wrote a letter charged with sadness to Egypt, in which were written the following words: «'Omar commands saying, Those who wish to remain as they are, and in their own country, must follow the religion of Muhammad as I do; but let those who do not wish to do so, go forth from my dominions». Then the Christians gave him all the money that they could, and trusted in God, and rendered service to the Muslims, and became an example to many. For the Christians were oppressed by the governors and the local authorities and the Muslims in every place, the old and the young, the rich and the poor among them; and 'Omar commanded

48 B. Evetts, History of the Patriarchs of the Coptic Church of Alexandria III. Patrologia Orientalis, vol. v, Paris, 1910, p. 42.

49 Evetts, History of the Patriarchs III, p. 51.

50 Evetts, History of the Patriarchs III, p. 51. 
that the poll-tax should be taken from all men who would not become Muslims, even in cases where it was not customary to take it. But God did not long respite him, but destroyed him swiftly, and granted him the government no longer, because he was like Antichrist." 51

This fragment clearly illustrates the concept of interchanging measures of positive and negative discrimination being a dominant way of Muslim authorities to conduct intrastate relationships.

HPA gives a thorough and presumably eye-witnessed description of the first Coptic uprising in 725, under the rule of Caliph Hishām, who was first considered by the Copts "the deliverer of the orthodox" for permitting them to elect a patriarch, and the de facto government of 'Ubayd Allah Ibn al-Habhab, who doubled the taxes, which, in turn, caused major confrontations between Christians and Muslims, and "much blood was shed in the land of Egypt between the two factions, and "first of all in the city of Banā and the city of Sa and the city of Samannūd and their neighbourhood, and in many places in Lower Egypt; and there was likewise fighting on the roads and mountains and by the canals." 52

A mass transition of Copts to Islam is reported by both Muslim and Coptic chronicles around 740, and HPA is not an exception. But due to the specifically emotional nature of the Coptic sources en masse and the History of the Patriarchs itself, we find that the Coptic Church and its leaders did despise those who abandoned their faith. ${ }^{53}$

There is also a peculiar fragment dating back to the reign of governor Abū 'Awn 'Abd al-Mālik ibn Yazīd (755-758), describing a miracle caused by Christian prayers - the rise of the Nile. Though being not an actual deed of the Copts, it still caused some positive change in their position and gave them some years of security, accompanied by measures of positive discrimination: "And as for 'Abu 'Aun, for this reason he increased his benefits towards the Christians and their churches, and lightened their taxes." ${ }^{\text {4 }}$

The "History of the Patriarchs..." also notes a story that took place during the Arab-Byzantine wars, circa 780, about Christian captives who were forced to become Muslims: "when our father Mark saw these captives, he was grieved because human beings were sold, as if they were cattle; moreover many of them became Muslims. And because his heart was compassionate he redeemed many of them, such as monks and priests and deacons and virgins and

$51 \quad$ Evetts, History of the Patriarchs III, p. 72.

$5^{2}$ Evetts, History of the Patriarchs III, p. 72.

53 Evetts, History of the Patriarchs III, p. 117.

54 Evetts, History of the Patriarchs III, p. 198. 
mothers of children, until he had bought as many as six thousand souls. When he purchased one of these prisoners, he wrote a deed of emancipation for him on the spot, and gave into his hand a letter which set him free". 55

Generally, HPA does not note any particular violence or persecution during the 'Abbasid reign, paying more attention to inner problems of the Church. Nevertheless, the taxes were still in place and questionable policies of certain governors and caliphs are mentioned, for example, this account of caliph alMutawakkil's reign: "He ordered all the churches to be demolished, and that none of the Orthodox Christians, Melkites, Nestorians, or Jews should wear white garments, but that they should wear dyed garments, so that they might be distinguished among the Muslims. He ordered that frightful pictures should be made on wooden boards and that they should be nailed over the doors of the Christians. He forced most of them (to embrace) al-Islam, and ordered that Christians should not serve in the employment of the Sultan at all, but only Muslims and those who had gone over to al-Islam. <>He dismissed the Christian ministerial secretaries from the diwān of the Sultan and substituted Muslims in their stead." 56

Surprisingly, soon after this al-Mutawakkil appointed a new governor of Egypt, Yazīd ibn 'Abdallah al-Hulwāni, who stopped these measures and convinced the Caliph to restore some cities. ${ }^{57}$

Besides some brief periods of tax oppression(which is claimed to have been equally hard for the Muslim population $)^{58}$, the period of time from the late 'Abbasid rule up to the middle of the Fatimìd dynasty reign was quite peaceful, and the chronicle does not mention much persecution against the Christians. ${ }^{59}$

The authors of the History of the patriarchs give a very explicit account of caliph al-Hākim, his reign, his personality and his deeds. This very much corresponds to the fact that al-Hākim has a distinct place in the national memory of the Copts, as no other caliph has as many passages and even pages describing him. ${ }^{60}$ As for the persecutions and regulations he imposed on the dhimmis, the chronicle also gives a very detailed account, and clearly, those measures were unprecedentedly heavy, which underlines the fact that al-Hākim's reign

55 Evetts, History of the Patriarchs IV, p. 430.

56 O.H.E. Burmester, Yassa Abd al-Masih, History of the Patriarchs of the Egyptian Church, Known as the History of the Holy Church of Sawirus ibn al-Mukaffa', Bishop of al-Asmunin, Vol. II part I, Cairo, 1943, p. 7 .

57 Burmester, Abd al-Masih, History of the Patriarchs Vol. II part I, p. 15.

$5^{8}$ Бартольд, Культура мусульманства, рр. 24-25.

59 O.H.E. Burmester, Yassa Abd al-Masih, Aziz S. Atiya, History of the Patriarchs of the Egyptian Church, Known as the History of the Holy Church of Sawirus ibn al-Mukaffa, Bishop of al-Asmunin. Vol. II part II, Cairo, 1948, p. 234.

6o Burmester et al., History of the Patriarchs, Vol. II part II, p. 187. 
was the final turning point in the process of the Copts' transformation into a discriminated minority. This is what H PA accounts on those: “...he ordered that the crosses which were upon the domes of the churches should be pulled down, and that the crosses which were upon the hands of the people should be erased. Then he ordered that the Christians should have a belt fastened round their waists and that they should wear black turbans on their heads and that they should ride with wooden stirrups and that none of them should ride with iron stirrups, and that they should wear crosses a span in length, then he ordered again to make them (the crosses) a cubit and a half (in length). (He ordered) that the Jews should dye the borders of their turbans and that they should wear belts and that they should make (for themselves) a wooden ball in the form of the head of the calf which they worshipped in the desert, and that none of the Christians and Jews should enter a bath with Muslims.<...> Many of the Christians and the Jews from their chiefs (down) to the lowest of them denied (their faith) on account of this, and they did not endure patiently this disgrace and affliction." 61

It is widely known ${ }^{62}$ that al-Hākim's successors applied measures of positive discrimination to Christians and other dhimmis, but H PA gives a surprising account of the time around 1019-20, just before the Caliph's mysterious disappearance: "In this decree he (al-Hākim) exempted them (the Christians) from wearing the ghiyar and from wearing the cross, and (allowed) them to strike the nawakis in all the churches in every place, as was their custom. $O$ what joy was it on that day for all the Christians who were in the land of Misr In the year in which there was deliverance and the allowance to undertake restorations in the churches, a wonderful thing was manifested." 63

Al-Hākim was succeeded by his son al-Zāhir, whose reign is described as a time of prosperity, security and respect to the Coptic Church: "The religion of the Christians was in a good state and its people respected. In his (Az-Zāhir's) days the churches were (re)built till they returned to the state (in which) they had been, and (were even) better. The (re)building in them (the churches) did not cease and the restoration was continued till the year in which this biography was written, and it is the year seven hundred and sixty-seven of the Martyrs [A.D. 1050-1051]."64

Basing on the accounts given by this chronicle, it can be stated that interchanging periods of positive and negative discrimination were one of the main

$61 \quad$ Burmester et al., History of the Patriarchs, Vol. II part II, p. 189.

62 E.g. O. Meinardus, Christian Egypt Faith and Life, Cairo, 1970, p. 361.

63 Burmester et al., History of the Patriarchs, Vol. II part II, p. 209.

64 Burmester et al., History of the Patriarchs, Vol. II part II, p. 210. 
features of the relationships between the Coptic Church and Muslim authorities of Egypt in VIIth-XIth centuries. Severe taxation and other measures caused many Copts to abandon their faith and become Muslims, so during the described period the Coptic community significantly sank in numbers, which could not but influences their identity. The descriptions in the chronicle also confirm the theory of the Copts having an opportunity of self-selection between identities, because though experiencing grief, the Church and its fathers did not impose any sanctions on those who were forced to become Muslims. One of the main commandments of the Coptic Church was to humbly accept what was given to them by God in terms of trials or kindness, and so they did, trying to maintain the balance in the church-state relationships and developing diplomacy in order to avoid conflict.

\section{Conclusion}

Basing on the analysis of the sources available, it is possible to state that the balance between interchanging periods of positive and negative discrimination was a solid trend in the medieval history of the Coptic Church and community. The liberal policies of the first Muslim rulers did not last long, followed by the period of repression, which caused Christians to abandon their faith and begin their way to becoming a discriminated social group. But at the same time, accepting Islam gave the Copts a possibility of integration to privileged Muslim class. Due to this possibility and as well the processes of Islamization and Arabization of Egypt, by the Ixth century the Copts had gradually ceased to be a numerical majority, becoming a smaller ethno-confessional group more prone to discrimination. During the 'Abbasid reign mass social protest developed against the 'dominance' of the Copts, which resulted in significant damage to the chances of their integration to the Muslim society of Egypt.

The times of relative stability under the Tulunīd, Ihshidīd and Fatimīd dynasties brought the Copts to the highest administrative positions, making them a part of the country's elite. Despite some exceptions, the period of Fatimīd and the following Ayyubīd reign (969-1252) can be characterized as a period of prosperity and definitely positive discrimination of the Copts. This situation continued up to the middle of XIvth century, when the beginning of the decline of the Mamluk sultanate brought severe repression, extermination and negative discrimination on the heads of the Copts.

Thus, it can be said that the position of the Copts in medieval Egypt was quite bilateral, and in the course of time they experienced both the positive and negative discrimination. On the one hand, the Copts were often appointed 
to higher administrative positions and took a significant place in the life and administration of the Egyptian court, due to their high cultural level and profound implementation of some fiscal, notary and direct administrative functions. But on the other hand, they kept being an oppressed group of low social status, unequal to Muslims in terms of rights, experiencing severe tax policies, religious discrimination and forced to comply with a number of social and domestic constraints.

It can be stated that negative discrimination followed by measures of positive was used by Muslim rulers to keep the Copts at bay, but still enjoy the benefits of their existence. Such policy created a significant socio-economic gap, both between the Muslims and Christians, and inside the Coptic community itself. This question is very important for understanding the specifics of intrastate relations in medieval Egypt and relations between Christians and Muslim authorities in general, so surely deserves deeper study. 